\title{
Muzułmańskie echa wizyty Hadży Seraji Szapszała w Jugosławii w 1936 roku
}

\author{
Mariusz Pawelec \\ Uniwersytet Śląski w Katowicach, Wydział Nauk Społecznych
}

\section{Muslim echoes of the visit of Hadji Seraya Shapshal to Yugoslavia in 1936}

\begin{abstract}
Summary: In the summer of 1936 Hadji Seraya Khan Shapshal undertook an academic excursion to Belgrade and Sarajevo accompanied by a group of Oriental studies students from Vilnius. His visit made a great impression on Muslim circles in both Poland and Yugoslavia. Fetih Bajraktarević and Mehmed Handžić, two eminent representatives of the Muslim communities in Yugoslavia, spoke publicly on the religion of Karaites which was identified as lying somewhere between Judaism and Islam. They also emphasized the important role of Shapshal as a spiritual leader, Orientalist and collector.
\end{abstract}

Keywords: Seraya Shapshal, Yugoslavia, Karaims, karaimism, Islam, Oriental studies, manuscripts.

Latem 1936 r. karaimski hachan Hadży Seraja Chan Szapszał odbył kilkutygodniową podróż na Bałkany, odwiedzając w jej trakcie m.in. Jugosławię. Oficjalnym celem podróży było skontaktowanie się z diasporą Karaimów, którzy po ewakuacji z ogarniętej wojną domową Rosji osiedlili się w Królestwie Serbów, Chorwatów i Słoweńcow (SHS). Jako zwierzchnik religii karaimskiej Szapszał sprawował duchową opiekę nad współwyznawcami rozsianymi po kilkunastu krajach Europy. Wspomnianą podróż wykorzystał on także w celach 
kolekcjonerskich. Jako zbieracz orientaliów poszukiwał wśród Karaimów oraz na rynku antykwarycznym caraimików, które miały wzbogacić mające powstać w Trokach w bliskiej przyszłości Muzeum Karaimskie. Belgrad zaś był miejscem, gdzie jeszcze w drugiej połowie XVII w. funkcjonowała religijna gmina karaimów1. Wyjazd do Jugosławii stwarzał ponadto dla Szapszała możliwość odnowienia dawnych i nawiązania nowych kontaktów naukowo-towarzyskich.

Państwo południowych Słowian pod rządami prorosyjskiej serbskiej dynastii Karadziordziewiczów w latach 20. XX w. z otwartością odniosło się do „pierwszej fali” rosyjskiej emigracji ${ }^{2}$. Na terytorium Królestwa SHS znalazło się spore skupisko wychodźców z Rosji, wśród których nie brakowało także Karaimów ${ }^{3}$. Nie tworzyli oni zwartego środowiska, a raczej pozostawali rozproszeni po dużych miastach, jak Belgrad i Zagrzeb, ale także małych miejscowościach, jak Padej w Banacie, gdzie osiedlił się Salomon Mangubi, pułkownik rosyjskiego korpusu straży pogranicza. Jednym ze znaczących przedstawicieli diaspory karaimskiej był bratanek hachana, profesor anatomii na uniwersytecie belgradzkim, Ilia Szapszał. Jednak już w 1923 r. przeniósł się z Novego Sadu do Sofii, gdzie prowadził wykłady na tamtejszym uniwersytecie. Znacznie częstszym kierunkiem dalszych migracji Karaimów przebywających tymczasowo nad Sawą i Dunajem była Francja. W tymże samym 1923 r. opuścił Zagrzeb i przeprowadził się do Paryża Josif Pampułow. Tam też jeszcze w latach 20. udał się z rodziną Aleksandr Penbek. Podobną decyzję podjęła rodzina Semiona Saracza. Jeden z jego synów, Michaił (późniejszy prawnik i mecenas wydawnictw poświęconych kulturze i historii Karaimów) ukończył jeszcze przed

1 E. Čelebī, Putopis. Odlomci o jugoslovenskim zemljama, preveo, uvod i komentar H. Šabanović, Sarajevo 1996, s. 195-198. W pochodzącym z 1660 r. opisie miasta Ewlija Czelebi wspomniał wspólnotę karaimską, która jednak pozbawiona była własnej świątyni.

2 Zagadnienie posiada bogatą literaturę zob. Russkaâ èmigraciâ v Ûgoslavii, red. kollegiâ A. Arsen'ev, O. Kirillova, M. Sibinovič, Moskva 1996; V.D. Kozlitin, Russkâa i ukrainskaâ èmigraciâ v Ûgoslavii (1919-1945 gg.), Xar'kov 1998; J. Kačaki, Ruske izbeglice u Kraljevini SHS/Jugoslaviji. Bibliografija radova 1920-1944, 2 wyd., Beograd 2003; M. Jovanovič, Russkaâ èmigraciâ na Balkanah, Moskva 2005; E.A. Bondareva, Pax Rossica. Russkaâ gosudarstvennost'v trudah istorikov zarubežâ, Moskva 2012.

3 D.A. Prohorov, Krymskie karaimy v sostave Vooružennyh sil Ûga Rossii (1918-1920), Vestnik Kemerovskogo gosudarstvennogo universiteta 2015, nr 2, t. 6 (62), s. 291. Wykaz Karaimów służących w szeregach „białych” i ich emigracyjnych losów w bazie: S.V. Volkov „Učastniki Belogo dviženiâ v Rossii”: http://swolkov.org/2_baza_beloe_dvizhenie/2_baza_beloe_dvizhenie_abc-01.htm [data dostępu: 11.09.2016]. 
wyjazdem z Serbii rosyjską szkolę kadetów. Inni, młodzi oficerowie rosyjskiej armii swą przyszłość postanowili związać z Belgradem. Sergiej Szapszał, kapitan lotnictwa, po demobilizacji ukończył fakultet techniczny uniwersytetu belgradzkiego. Działał również w związku studentów gallipolijczyków (Сою3 студентов галлиполийев), będąc sekretarzem jego zarządu. Podobnie porucznik Sulejman Szapszał, który w 1922 r. na tejże uczelni był członkiem związku rosyjskich studentów (Союз русских студентов). Niektórzy zaś w naturalny sposób odchodzili, jak lekarz Semen Penbek, zmarły w 1931 r. w miejscowości Pančevo w Wojwodinie.

Według oficjalnych (choć zapewne niepełnych) danych jugosłowiańskich, w 1931 r. osób deklarujących narodowość i wyznanie karaimskie na terytorium tego państwa było zaledwie dziesięcioro (8 mężczyzn i 2 kobiety) ${ }^{4}$. Wynikało to z jednej strony z faktu, że jeszcze w latach 20. część osób narodowości karaimskiej wyemigrowała do zasobniejszych krajów Europy Zachodniej lub USA, część zaś zasymilowała się w środowisku rosyjskiej kolonii. W międzywojennej Jugosławii nie zaistniało żadne odrębne karaimskie stowarzyszenie ${ }^{5}$.

Nie są znane szczegóły kontaktu hachana z rodakami podczas jego pobytu w tym kraju w 1936 r. W zbiorze dokumentów S. Szapszała przechowywanym obecnie w Bibliotece Litewskiej Akademii Nauk w Wilnie nie zachowała się też żadna fotografia $\mathrm{z}$ takiego spotkania. Musiał on jednak dysponować stosowną wiedzą o karaimskim skupisku w Jugosławii. Według bowiem jego szacunków dla polskiego Ministerstwa Wyznań Religijnych i Oświecenia Publicznego, w końcu lat 30. grono Karaimów zamieszkujących ten kraj liczyło niespełna 20 osób, byłych oficerów armii rosyjskiej, zatrudnionych w większości w państwowych urzędach ${ }^{6}$.

W przeszłości Belgrad (hebr. Ir Levana 'białe miasto') stanowił znaczący ośrodek karaimizmu na Bałkanach. Na przełomie XV i XVI w. działał tam słynny karaimski uczony Kaleb ben Elija Afendopolo, jego brat Samuel zwany Rahmati, a także poeta liturgiczny i kopista dzieł religijnych Juda ben Elija Tiszbi . Niektó-

\footnotetext{
$4 \quad$ M. Jovanovič, op. cit., s. 138, 140.

5 M. Sarač, Rossijskaâ èmigraciâ i krymskie karaimy vo Francii, [w:] Krymskie karaimy. Proishoždenie, ètnokul'tura, istoriâ, Simferopol', 2005, s. 91.

6 M. Abkowicz, Działalność organizacyjna Karaimów z pierwszej fali emigracji rosyjskiej $w$ przededniu II wojny światowej na podstawie korespondencji z hachanem Serają Szapszałem, „Almanach Karaimski” 2014, nr 3, s. 10.

7 A. Fotić, Belgrade: A Muslim and non-Muslim cultural centre (sixteenth-seventeenth centuries), [w:] Provincial elites in the Ottoman Empire, ed. A. Anastasopoulos, Rethymno 2005, s. 73.
} 
re z ich dzieł zostały napisane lub skopiowane właśnie w Belgradzie. Stwarzało to nadzieję na możliwość zachowania dawnych rękopiśmiennych caraimików w tamtejszych kolekcjach. Czy Szapszał istotnie trafił na ich ślad w trakcie wizyty w stolicy Jugosławii - trudno stwierdzić. Faktem jest, że w materiałach pozostałych po nim znajduje się zbiór fotografii i pocztówek pochodzących z Sarajewa i innych miast tego kraju. Przedstawiają one charakterystyczne typy muzułmańskiej ludności oraz przykłady tradycyjnej architektury Bośni ${ }^{8}$. Także niektóre przedmioty rzemiosła artystycznego z kolekcji Szapszała stanowią wyrób bośniackich rzemieślników ${ }^{9}$. Zostały zatem zakupione prawdopodobnie podczas pobytu w Jugosławii w $1936 \mathrm{r}$.

Podróż miała też na celu wzmocnienie jego osobistych kontaktów jako karaimskiego hachana i badacza tematyki orientalnej. Seraja Szapszał był postacią znaną na Bałkanach, a zwłaszcza w Serbii, dużo wcześniej. Dwadzieścia lat wstecz, w 1916 r., uhonorowany został w Petersburgu serbskim Orderem Świętego Sawy drugiego stopnia. Order ten przyznawany był m.in. osobom duchownym za zasługi w dziedzinie nauki, sztuki oraz działalności religijnej. Szapszał otrzymał to odznaczenie po wybraniu go w 1915 r. hachanem taurydzkim. Oprócz docenienia dla dokonań naukowych i aktywności na polu dyplomacji uhonorowanie to, przyznane przez regenta Serbii Aleksandra Karadziordziewicza, stanowiło również potwierdzenie zaufania, jakim cieszył się Seraja Szapszał na dworze Romanowów oraz w rosyjskich sferach rządowych (sam książę-regent młodość przeżył w Petersburgu, kończąc w 1906 r. prestiżową szkołę wojskową, tj. Korpus Paziów). Lata spędzone przez Szapszała na emigracji w Turcji (1921-1928) pozwoliły mu na kontynuowanie zainteresowań naukowych poświęconych orientalistyce. Zwłaszcza jego publikacja Kırm Karai Türkler $i^{10}$ uczyniła znanym jego nazwisko. Pobyt w Konstantynopolu to również zaangażowanie się Szapszała w życie tamtejszej rosyjskiej kolonii. W imieniu emigrantów uczestniczył m.in. w działaniach mających na celu umożliwienie zdemobilizowanym oficerom rosyjskim uzyskania wykształcenia w Turcji. Udając się po latach już jako hachan trocki do Jugosławii, mógł spodziewać się pozytywnego przyjęcia ze strony czynników oficjalnych Jugosławii, jak

$8 \quad$ Z. Būčys (ed.), Seraya Szapszal's Karaim collection, Vilnius 2003, s. 36, 146.

9 Ibidem, s. 69, 71, 88.

10 S. Şapşaloğlu (= Szapszał), Kırım Karai Türkleri, „Türk Yılı”, İstanbul 1928, s. 576-615. Współczesna edycja: S. Şapşaloğlu, Kırım Karaî Türkleri, [w:] Y. Akçuraoğlu, Türk Yll 1928, A. Tekin, A.Z. Izgöer (eds.), Ankara 2009, s. 605-650, por. T. Çulha (ed.), Sereya Şapşal'a Göre Karay Türkleri ve Karayca, „Türk Dilleri Araştırmaları”, 2002, 12, s. 97-188. 
i wyrazów życzliwości ze strony diaspory rosyjskiej. Jednym z dawnych znajomych był turkolog Aleksiej Olesnickij (1888-1943), przed wybuchem rewolucji współpracownik Środkowoazjatyckiego Oddziału MSZ Rosji. Po ewakuacji przez Konstantynopol, osiadł na stałe w Zagrzebiu. Od 1928 r. byl nieetatowym pracownikiem Jugosłowiańskiej Akademii Nauk. Zajmował się odnajdywaniem i naukowym opracowywaniem tureckich, arabskich i perskich rękopisów w archiwach Belgradu, Zagrzebia i Sarajewa. Szapszał wznowił z nim kontakt korespondencyjny w 1928 r., a w 1937 r. spotkali się po raz kolejny i ostatni jednocześnie ${ }^{11}$.

Wyjazd na Bałkany miał też i inny aspekt naukowy. Szapszałowi towarzyszyła bowiem grupa młodzieży skupiona w Kole Turkologów działającym w Szkole Nauk Politycznych w Wilnie ${ }^{12}$. W tej uczelni działającej przy Instytucie Naukowo-Badawczym Europy Wschodniej dr Seraja Szapszał prowadził wykłady z języka tureckiego dla słuchaczy czterech pierwszych semestrów w wymiarze po 30 godzin na semestr ${ }^{13}$. Jako kierujący lektoratem był również kuratorem tegoż Koła. Jego członkowie częściowo wywodzący się ze środowiska tatarskiego blisko współpracowali z wileńskim Kołem Młodzieży Tatarskiej ${ }^{14}$. Już od 1934 r. Szapszał organizował dla członków studenckiego Koła Turkologów wycieczki naukowe do Turcji i na Bałkany. W ich trakcie mieli oni możność zapoznania się bliżej zarówno z przeszłością, jak i dniem współczesnym wspólnot muzułmańskich w Europie południowo-wschodniej. Niewątpliwy autorytet Szapszała zadecydował o aktywnym zaangażowaniu członków Koła Turkologów w organizacji odbywającego się w Wilnie rok później (20-22 VI 1937 r.) VI Zjazdu Polskich Orientalistów. Jedna z jego sesji poświęcona zagadnieniom turkologicznym odbyła się nawet w siedzibie Koła, w budynku Biblioteki im. Wróblewskich użytkowanym przez Szkołę Nauk Politycznych przy ul. Arsenalskiej $8^{15}$.

11 I.V. Zajcev, Trudy i dni Alekseâ Akimoviča Olesnickogo. (Addenda k slovarû otečestvennyh turkologov), „Shidnij svit” 2009, nr 1, s. 5-12.

12 H. Ilgiewicz, Szkoła Nauk Politycznych przy Instytucie Naukowo-Badawczym Europy Wschodniej w Wilnie (1930-1939), „Rocznik Stowarzyszenia Naukowców Polaków Litwy” 2014, nr 13/14, s. 43.

13 Szkoła Nauk Politycznych $w$ Wilnie. Spis wykładów i grono nauczające w roku akademickim 1935/36, Wilno 1935, [br. pag.].

14 U. Wróblewska, Sytuacja oświatowa społeczności tatarskiej w Drugiej Rzeczypospolitej, „Klio” 2012, nr 21 (2), s. 184.

15 Kronika: VI Zjazd orientalistów polskich, „Rocznik Orjentalistyczny” 1937, nr 13, s. 211-213. 
Początkowo udział w wakacyjnej wyprawie planował również trocki Karaim, od 1935 r. prof. katedry turkologii Uniwersytetu Warszawskiego, Ananiasz Zajączkowski. Wynika tak z jego korespondencji kierowanej do prof. Tadeusza Kowalskiego. Ostatecznie, w sierpniu 1936 r. zamiast do Sarajewa Zajączkowski udał się do Stambułu na III Kongres (Kurułtaj) Językoznawczy ${ }^{16}$. Echem podróży grupy polskich Tatarów do Bośni stał się natomiast artykuł dr. Stefana Bazarewskiego pt. Muzulmanie w Jugosławii opublikowany na przełomie 1936/1937 r. na łamach „Życia Tatarskiego”"17.

Okazuje się jednak, że pobyt Hadży S. Szapszała w Jugosławii latem 1936 r. zaowocował również publikacjami poświęconymi jego osobie, powstałymi w środowisku bałkańskich muzułmanów. Autorem jednej z nich był Hadži Mehmed Handžić (1906-1944), młody i obiecujący teolog islamski (alim), który po studiach na Uniwersytecie Al-Azhar w Kairze (1926-1931) został wykładowcą Gazi Husrev-beg Madrasa w Sarajewie, najstarszej średniej szkoły islamskiej na Bałkanach założonej w 1537 r. W wydawanym w stolicy Bośni czasopiśmie „Novi Behar” Handžić opublikował w listopadzie 1936 r. artykuł pt. Karaimi $\left(\right.$ Karaiti) ${ }^{18}$. Poświęcony został on tematyce religii i historii wspólnoty karaimskiej, a oparty - jak podaje jego autor - na wspomnianej publikacji Kırım Karai Türkleri Szapszała z 1928 r.

Bezpośrednią przyczyną przybliżenia bośniackim muzułmanom tego mało znanego zagadnienia stała się wizyta w Sarajewie karaimskiego hachana. Jak informuje Handžić, doszło do niej w końcu lipca i w początkach sierpnia $1936 \mathrm{r}$. W gronie gości przybyłych z Polski znalazła się, czego też nie omieszkał podkreślić, muzułmanka imieniem Zofia (Safije hanuma). Przedstawiając postać Szapszała zaznaczył, że jest on duchowym przywódcą Karaimów na całym świecie, a wcześniej był nauczycielem następcy tronu perskiego oraz wykładowcą na uniwersytecie w Petersburgu. Zna turecki, perski, tatarski, uzbecki, rosyjski, francuski, polski i jeszcze inne języki. Obecnie pełni obowiązki wykładowcy wyższej szkoły nauk politycznych w Wilnie. Jego studentem w czasach petersburskich był - jak twierdzi Handžić - Hadży Jakub Szynkiewicz, w okresie

16 T. Majda (ed.), Urzeczeni Orientem. Listy Profesora Ananiasza Zajączkowskiego do Profesora Tadeusza Kowalskiego, Warszawa 2013, s. 107 poz. 56.

17 S. Bazarewski, Muzułmanie w Jugosławji, „Życie Tatarskie” 1936, nr 12, s. 267-269; 1937, nr 1, s. 4-5, 7; nr 2, s. 6-8.

18 M. Handžić, Karaimi (Karaiti), „Novi Behar” 1936-1937, 10, br. 6-9, s. 92-94, por. M. Busuladžić, Lo scrittore Hadži Mehmed Handžić di Sarajevo, „Oriente Moderno” 1942, 22, nr 4, s. 172, 177 poz. 49; A. Kantardžić (ed.), Bibliografija Novog Behara, Sarajevo 2007, s. 95, poz. 964. 
międzywojennym mufti polskich muzułmanów ${ }^{19}$. Rzeczywiście, w 1910 r. Szynkiewicz przerwał studia w Instytucie Technologicznym w Petersburgu i przeniósł się na wydział języków orientalnych tamtejszego uniwersytetu, gdzie lektorem języka tureckiego był Szapszał. Ten szczegół dotyczący początków ich znajomości nie był dotąd znany badaczom biografii obu przywódców religijnych ${ }^{20}$.

Nie mniej interesująca jest wzmianka o polskiej muzułmance w gronie wileńskich studentów towarzyszących Szapszałowi w wyprawie na Bałkany. Postacią tą była najprawdopodobniej Zofia Romanowiczówna, córka płka Jakuba Romanowicza, tatarskiego ziemianina z powiatu lidzkiego. Był on w okresie międzywojennym aktywnym działaczem Gminy Muzułmańskiej w Wilnie (członek zarządu), Muzułmańskiego Związku Religijnego w RP (zastępca muftiego oraz członek Najwyższego Kolegium) oraz Związku Kulturalno-Oświatowego Tatarów w RP (członek Rady Centralnej) ${ }^{21}$. Zofia Romanowiczówna studiowała historię na Uniwersytecie Stefana Batorego w Wilnie. Obszarem jej naukowych zainteresowań było zagadnienie osadnictwa tatarskiego w Wielkim Księstwie Litewskim. Rozprawa magisterska pisana pod kierunkiem prof. Stanisława Kościałkowskiego pt. „Tatarzy w ekonomiach królewskich (XVII i XVIII w.)” była gotowa w 1939 r., lecz wybuch wojny uniemożliwił jej obronę $^{22}$. Z tematyki historycznej Romanowiczówna opublikowała w 1934 r. na łamach „Życia Tatarskiego” artykuł Tatarzy w Łosośnie $e^{23}$. Była czynnie zaangażowana w działalność Związku Kulturalno-Oświatowego Tatarów, będąc jego członkiem zarządu głównego ${ }^{24}$. Jej udział w wycieczce naukowej młodzieży wileńskiej pozwala sądzić, że uczestniczyli w niej nie tylko studenci Szkoły Nauk Politycznych, ale również uniwersytetu wileńskiego oraz innych uczelni. Symbolicznym wyrazem ówczesnych relacji karaimsko-tatarskich stało się jej małżeństwo z Michałem Maszkiewiczem, Karaimem z Wilna.

19 M. Handžić, op. cit., s. 92.

20 S. Chazbijewicz, Przyczynek do relacji tatarsko-karaimskich wokresie międzywojennym i późniejszym: Hachan Hadży Seraja Szapszal i mufti dr Jakub Szynkiewicz, „Almanach Karaimski” 2014, nr 3, s. 152; S. Gąsiorowski, Szynkiewicz Jakub, [w:] Polski Słownik Biograficzny, red. A. Romanowski, t. 50, Kraków - Warszawa 2015, s. 321.

21 S. Konarski, Romanowicz Jakub, [w:] Polski Słownik Biograficzny, red. E. Rostworowski, t. 31, Wrocław [et al.] 1988-1989, s. 592.

22 J. Tyszkiewicz, Międzywojenne badania nad dziejami Tatarów litewsko-polskich w XVII stuleciu, „Przegląd Historyczny” 1985, nr 76/2, s. 318.

23 Z. Romanowiczówna, Tatarzy w Eosośnie, „Życie Tatarskie” 1934, nr 12, s. 18-20; por. L. Kryczyński, Bibljografja do historji Tatarów polskich, Zamość 1935, s. 53 poz. 1695.

24 Kronika (15.V.1932 - 15.VI.1935), „Rocznik Tatarski” 1935, t. 2, s. 470, 480. 
Artykuł Handžića, będący omówieniem wspomnianej pracy Szapszała (stała się ona dysertacją umożliwiającą uzyskanie w 1930 r. tytułu doktorskiego na Uniwersytecie Jana Kazimierza we Lwowie), skupił się na tematyce religijnej dotyczącej karaimizmu. Opisując jego genezę, wykazał m.in. różnice występujące między religią karaimską a judaizmem, uwypuklając jednocześnie podobieństwa wobec islamu. Początki tego kierunku religijnego sięgają VIII w. i wiążą się z postacią pobożnego uczonego Anana ibn Dauda. Pojawił się on w wśród Żydów w Mezopotamii, skupiając wokół siebie licznych przeciwników tradycji ustnej w wierze żydowskiej. Nazwali oni siebie początkowo Bene Mikra („Synowie świętych ksiąg”). Odrzucenie Talmudu naraziło ich na wrogość pozostałych Żydów. Z powodu tego sporu, za panowania kalifa Abu al-Mansura, Anan został uwięziony. Jak utrzymują karaimscy duchowi autorzy, zetknął się on tam z również pozbawionym wolności Wielkim Imamem (A'zam Imam) Abu Hanifą. Wywarł on na Anana znaczący wpływ tak, że ten uznał prorocze posłannictwo Muhameda oraz zasadę analogii w interpretacji prawa (kijas). Uwolniony przeniósł się potem do Jerozolimy, gdzie utworzył pierwsze karaimskie miejsce zgromadzeń, położone w obawie przed prześladowaniami pod powierzchnią ziemi. Istnieje ono zresztą - jak informuje Handžić - po dziś dzień. Bośniacki teolog zamieścił następnie treść dziesięciu artykułów wiary, które tworzą fundament wierzeń karaimskich. Wraz z odrębnymi rytuałami i przepisami decydują one o różnicach w stosunku do praktyk religijnych innych Żydów ${ }^{25}$.

Sporo miejsca poświęcił w swym artykule omówieniu etnicznego pochodzenia Karaimów krymskich oraz kwestii dotarcia idei karaimizmu na Krym. Idąc śladem Seraji Szapszała, umiejscowił ten fakt w czasach kagana Chazarów Bułana, przypisując działalności misyjnej Izaaka Sangari. Karaimizm upowszechnił się na wskutek konwersji części ludności kaganatu chazarskiego. Tym samym Karaimi krymscy pozostają zarówno pod względem krwi, jak i języka ludem tureckim. Świąteczna chutba wygłaszana jest u nich w języku narodowym, i co niezwykłe, jest w niej wspomniany muzułmański kalif, święte miasta Jerozolima, Medyna i Mekka oraz krymski chan. Modlitwa dotyczy również muftiego, kadi-askerów i mułłów, a dopiero na końcu wymieniani są ich starsi duchowi ${ }^{26}$.

Istniejące na Krymie karaimskie miejsca kultu wyglądają - jak podaje bardzo podobnie do muzułmańskich meczetów. W ich wnętrzach rozłożone

\footnotetext{
25 M. Handžić, op. cit., s. 93.

26 Ibidem.
} 
są dywany lub maty i każdy przy wejściu musi zdjąć obuwie. Przed miejscem kultu znajduje się fontanna dla dokonania prawidłowego oczyszczenia. Według świadectwa Surejja beja (autor artykułu posługuje się tureckim określeniem postaci), wielu muzułmanów na Krymie, którzy mieszkają w pobliżu karaimskich miejsc kultu, odmawia w nich modlitwę. Twierdzi on, że w tych miejscach, gdzie nie ma muzułmańskich cmentarzy, muzułmanie grzebią zmarłych na karaimskich nekropoliach i odwrotnie - tam, gdzie nie ma karaimskiego miejsca pochówku, tam zmarli karaimscy chowani są na cmentarzu muzułmańskim. O ile to prawda - zastrzega Handžić, - to są to bardzo rzadkie przypadki ${ }^{27}$.

Artykuł kończy się uwagą, iż karaimizm wart jest zainteresowania muzułmanów, gdyż spośród innych odłamów judaizmu i chrześcijaństwa usytuowany jest najbliżej islamu. Uznaje bowiem Boże posłannictwo Muhameda, pokój niech będzie nad nim (alejhiselam), choć nie odnosi jego posłannictwa do całej ludzkości, a tylko do muzułmanów ${ }^{28}$. Artykuł oprócz tych informacji zawiera także szczegóły świadczące o osobistym kontakcie autora z Szapszałem w Sarajewie latem 1936 r. Zdaje się to również potwierdzać wycinek prasowy z artykułem Handžića w materiałach po Szapszale z zamieszczoną datą wydania (1 listopada 1936 r. $)^{29}$.

Nieco inny w tematyce tekst, lecz także związany z osobą Seraji Szapszała, ukazał się w tym czasie w Belgradzie. Jego autorem był dr Fehim Bajraktarević (1889-1970) pochodzący również z Sarajewa jugosłowiański orientalista narodowości boszniackiej. Studia filologiczne odbył we Wiedniu, tam też doktoryzował się w 1918 r. W 1926 r. był współtwórcą seminarium filologii orientalnej Uniwersytetu Belgradzkiego, prowadząc wykłady z języka i literatury perskiej. W wydawanym przez wydział filologiczny tejże uczelni czasopiśmie naukowym „Прилози за књижевност, језик, историју и фолклор” opublikował on w 1937 r. obszerne, blisko 40-stronicowe opracowanie pt. О нашим Мевлудима и о Мевлуду yonume ${ }^{30}$.Zostało ono poświęcone powstałym na Bałkanach pieśniom (mevlud),

27 M. Handžić, op. cit., s. 92. O korzystaniu przez Karaimów z muzułmańskich miejsc zgromadzeń oraz o nekropoliach karaimsko-muzułmańskich (m.in. na Lipówce w Wilnie, gdzie spoczął w 1961 r. S. Szapszał) wspomina S. Chazbijewicz, Zbawienie niemuzułmanów z perspektywy islamskiej, „Więź” 2001, nr 5, s. 49.

28 M. Handžić, op. cit., s. 94. Etnologiczna bibliografia opisała tematykę artykułu: „Karaiti. Vjerska sekta najbliža islamu”, zob. L. Topali, Bibliografija za 1937. godinu (s dopunama za 1936.), „Etnografska istraživanja i građa” 1940, knj. 2, s. 182.

29 Lietuvos mokslų akademijos biblioteka, Vilnius, LMAB RS, fondas 143, no. 1492.

30 F. Bajraktarevič, O našim Mevludima i o Mevludu uopšte, „Prilozi za kniževnost, jezik, istoriju i folklor", kn. 17, 1937, sv. 1, s. 1-37. 
upamiętniającym narodzenie proroka Muhameda i wykonywanym podczas tradycyjnego święta Mevlud Bajram, przypadającego w trzecim miesiącu (rabi al-awwal) muzułmańskiego kalendarza. Dzięki pośrednictwu zaprzyjaźnionego turkologa z Krakowa, prof. Kowalskiego, Bajraktarević posiadł, jak podaje, wiadomość o fragmencie bośniackiego mewludu znajdującym się w kolekcji rękopisów karaimskiego orientalisty ${ }^{31}$. Belgradzki badacz już nieco wcześniej zapoznał się z treścią utworu liczącego 12 wersów, a teraz omówił go w kontekście innych zachowanych tekstów o tej tematyce. Tekst w języku boszniackim zapisany alfabetem arabskim wykazał pewne podobieństwa (ale i różnice) wobec mewludu napisanego w XIX w. przez Hafiza Saliha Gaševića.

Transkrypcję w serbskiej cyrylicy oraz szczegóły dotyczące zawartości i losów rękopisu, który nieoczekiwanie znalazł się w Wilnie, przedstawił Bajraktarević we wcześniejszym artykule pt. Једна нова версија српскога Мевлуда ogłoszonym w 1930 r., podobnie jak późniejszy w tym samym serbskim czasopiśmie $^{32}$. Jak się okazało w drodze korespondencji, Szapszał skopiował ów mewlud 5 grudnia 1927 r. w Konstantynopolu od przebywającego tam bośniackiego muzułmanina Hasana-Fehmi-bega Defterdarevića. Piśmiennictwo słowiańskich muzułmanów w języku narodowym utrwalane w alfabecie arabskim (aljamiado) posiadało pewne cechy wspólne z piśmiennictwem polsko-litewskich Tatarów, co podkreślił autor omówienia. Podobną zasadę posługiwania się „świętym” alfabetem ksiąg wyznaniowych do utrwalania piśmiennictwa religijnego i parareligijnego w języku etnicznym dostrzegł on również w odniesieniu do Karaimów.

Oprócz informacji o wspomnianej pieśni oba artykuły autorstwa Bajraktarevića przyniosły również garść wiadomości dotyczących Seraji Chana Szapszała oraz polskich Karaimów. Zaznaczył, że urodzony w Bachczysaraju kolekcjoner orientalnych rękopisów jest religijnym przywódcą (haham) wyznania karaimskiego, a jego siedzibą są Nowe Troki w pobliżu Wilna. Karaimi zostali sprowadzeni tam z Krymu w końcu XIV w. przez księcia litewskiego Witolda. Pod względem religijnym są odłamem judaizmu, a ich negatywny stosunek do tradycji talmudycznej pozwala określić ich - jak zauważa - mianem „protestantów judaizmu”. Posługują się oni alfabetem hebrajskim do zapisywania swej

31 Ibidem, s. 1, 14-15, por. M. Tayyib Okiç, Çeşitli Dillerde Mevlidler ve Süleyman Çelebi Mevlidinin Tercemeleri, Atatürk Üniversitesi İslâmî İlimler Fakültesi Dergisi, nr I, Erzurum 1975, s. 51.

32 F. Bajraktarevič, Jedna nova versija srpskoga Mevluda, „Prilozi za kniževnost, jezik, istoriju i folklor", kn. 10, 1930, sv. 1, s. 83-87. 
karaimskiej mowy, należącej do języków tureckich. Język zachodniokaraimski jest bardzo zbliżony do kipczackiego oraz kumańskiego, dzięki czemu może służyć jako klucz do zrozumienia znaczeń i fonetycznego obrazu Kodeksu Kumańskiego. Ponadto, jest on ostatnim żywym językiem spośród tureckich, który nie został narażony na wpływy islamu i jego językowe konsekwencje ${ }^{33}$. Bajraktarević opierał się na Hastings Encyclopedia of Religion and Ethics, popularnym wydawnictwie z dziedziny religioznawstwa, w którym zamieszczone zostało obszerne hasło poświęcone karaimom pióra dr. Samuela Poznańskiego ${ }^{34}$, a także pracy T. Kowalskiego Karaimische Texte (Kraków 1929) ${ }^{35}$.

Podróż Jego Eminencji Hadży Seraji Szapszała na Bałkany latem 1936 r. odbyła się w szczególnym momencie dla dwóch wspólnot religijnych w Rzeczypospolitej, muzułmańskiej i karaimskiej. Kilka miesięcy wcześniej polski parlament uchwalił ustawę o stosunku państwa do Muzułmańskiego Związku Religijnego w RP oraz Karaimskiego Związku Religijnego w RP, a obaj ich duchowni zwierzchnicy zostali odznaczeni Orderem Polonia Restituta drugiej klasy. Wspomniany akt prawny przyznawał karaimskiemu hachanowi szerokie prerogatywy m.in. w dziedzinie reprezentowania swego wyznania na arenie międzynarodowej. Potwierdzeniem tego był zapis o prawie do posiadania pieczęci z godłem państwowym. Władze II Rzeczypospolitej aprobowały i wspierały aktywność Hachana w relacjach zewnętrznych. Służyła ona bowiem kształtowaniu pozytywnego wizerunku Polski, pozwalając nierzadko również na prowadzenie zakulisowej dyplomacji lobbingowej ad hoc. Doświadczenie Szapszała nabyte podczas współpracy z rosyjskim MSZ było cenione, a jego znajomość muzułmańskiego Orientu nader przydatna dla polskich władz.

Ugruntowana pozycja Seraji Szapszała jako przedstawiciela niewielkiej przecież wspólnoty wyznaniowej, dobre stosunki z społecznością Tatarów polskich oraz jego dorobek naukowy i bogata kolekcja orientaliów zostały dostrzeżone i uznane przez znaczących przedstawicieli środowiska muzułmanów Jugosławii. Jego wizyta przyniosła zainteresowanie tematyką karaimską, czego ślady obecne są w ówczesnym piśmiennictwie.

\footnotetext{
33 Ibidem, s. 85-86.

34 S. Poznański, Karaites, [w:] Hastings Encyclopedia of Religion and Ethics, vol. 7, New York - Edinburgh 1915, s. 662-672.

35 T. Kowalski, Karaimische Texte im Dialekt von Troki, Kraków 1929.
} 


\section{Źródła archiwalne}

Lietuvos mokslų akademijos biblioteka, Vilnius, LMAB RS, fondas 143, no. 1492.

\section{Bibliografia}

Abkowicz, Mariola, Działalność organizacyjna Karaimów z pierwszej fali emigracji rosyjskiej $w$ przededniu II wojny światowej na podstawie korespondencji $z$ hachanem Seraja Szapszałem, „Almanach Karaimski” 2014, nr 3, s. 7-24.

Bajraktarevič, Fatih, Jedna nova versija srpskoga Mevluda, „Prilozi za kniževnost, jezik, istoriju i folklor”, kn. 10, 1930, sv. 1, s. 83-87.

Bajraktarevič, Fatih, O našim Mevludima i o Mevludu uopšte, „Prilozi za kniževnost, jezik, istoriju i folklor", kn. 17, 1937, sv. 1, s. 1-37.

Bazarewski, Stefan, Muzułmanie w Jugosławji, „Życie Tatarskie” 1936, nr 12, s. 267-269;

Bazarewski, Stefan, Muzułmanie w Jugosławji (Ciag dalszy), „Życie Tatarskie” 1937, nr 1, s. $4-5,7$.

Bazarewski, Stefan, Muzułmanie w Jugosławji (Dokończenie), „Życie Tatarskie” 1937, nr 2, s. 6-8.

Bondareva, Elena A., Pax Rossica. Russkaâ gosudarstvennost'v trudah istorikov zarubež â, Moskva: Veče, 2012.

Būčys, Zygintas (red.), Seraya Szapszal's Karaim collection, Vilnius: National Museum of Lithuania, 2003.

Busuladžić, Mustafà, Lo scrittore Hadži Mehmed Handžić di Sarajevo, „Oriente Moderno” 1942, 22, nr 4, s. 171-178.

Chazbijewicz, Selim, Przyczynek do relacji tatarsko-karaimskich w okresie międzywojennym i póżniejszym: Hachan Hadży Seraja Szapszał i mufti dr Jakub Szynkiewicz, „Almanach Karaimski” 2014, nr 3, s. 151-156.

Chazbijewicz, Selim, Zbawienie niemuzulmanów z perspektywy islamskiej, „Więź” 2001, nr 5, s. 45-52.

Čelebī, Evlijā, Putopis. Odlomci o jugoslovenskim zemljama, preveo, uvod i komentar Hazim Šabanović, Sarajevo: Sarajevo-Publishing, 1996.

Çulha, Tülay (ed.), Sereya Şapşal’a Göre Karay Türkleri ve Karayca, „Türk Dilleri Araştirmaları”, 2002, 12, s. 97-188.

Fotić, Aleksandar, Belgrade: A Muslim and non-Muslim cultural centre (sixteenth-seventeenth centuries), [w:] Provincial elites in the Ottoman Empire, ed. Antonis Anastasopoulos, Rethymno: Crete University Press, 2005, s. 51-76.

Gąsiorowski, Stefan, Szynkiewicz Jakub, [w:] Polski Słownik Biograficzny, red. Andrzej Romanowski, t. 50, Kraków - Warszawa 2014-2015, s. 321-324.

Handžić, Mehmed, Karaimi (Karaiti), „Novi Behar” 1936-1937, 10, br. 6-9, s. 92-94. 
Ilgiewicz Henryka, Szkoła Nauk Politycznych przy Instytucie Naukowo-Badawczym Europy Wschodniej w Wilnie (1930-1939), „Rocznik Stowarzyszenia Naukowców Polaków Litwy” 2014, nr 13/14, s. 30-47.

Jovanovič, Miroslav, Russkaâ èmigraciâ na Balkanah (1920-1940), Moskva: Russkij put', 2005.

Kačaki, Jovan, Ruske izbeglice u Kraljevini SXS/Jugoslaviji. Bibliografija radova 1920-1944, 2 wyd., Beograd: Knjižara Žagar 2003.

Kantardžić, Azra (ed.), Bibliografija Novog Behara, Sarajevo: Gazi Husrev-Begova Biblioteka, 2007.

Konarski, Stanisław, Romanowicz Jakub, [w:] Polski Słownik Biograficzny, red. Emanuel Rostworowski, t. 31, Wrocław [et al.] 1988-1989, s. 592-593.

Kowalski, Tadeusz, Karaimische Texte im Dialekt von Troki, Kraków: Polska Akademia Umiejętności, 1929.

Kozlitin, Vladimir D., Russkaâ i ukrainskaâ èmigraciâ v Ûgoslavii (1919-1945 gg.), Xar'kov: Knižnoe reklamnoe agenstvo „RA”, 1998.

Kronika (15.V.1932 - 15.VI.1935), „Rocznik Tatarski” 1935, t. 2, s. 466-484.

Kronika: VIZjazd orientalistów polskich, „Rocznik Orjentalistyczny” 1937, nr 13, s. 211-215.

Kryczyński Najman-Mirza, Leon, Bibljografia do historji Tatarów polskich, Zamość; nakł. autora, 1935.

Majda, Tadeusz (ed.), Urzeczeni Orientem. Listy Profesora Ananiasza Zajączkowskiego do Profesora Tadeusza Kowalskiego, Warszawa: AGADE 2013.

Poznański, Samuel, Karaites, [w:] Hastings Encyclopedia of Religion and Ethics, vol. 7, New York - Edinburgh: Charles Scribner's Sons and T \& T Clark, 1915, s. 662-672.

Prohorov, Dmitrij A., Krymskie karaimy v sostave Vooružennyh sil Ûga Rossii (1918-1920), Vestnik Kemerovskogo gosudarstvennogo universiteta 2015, nr 2, t. 6 (62), s. 288-294. Romanowiczowna, Zofia, Tatarzy w Łosośnie, „Życie Tatarskie” 1934, nr 12, s. 18-20.

Russkaâ èmigraciâ v Ûgoslavii, red. kollegiâ Aleksej Arsen'ev, Ol'ga Kirillova, Miodrag Sibinovič, Moskva: Indrik, 1996.

Sarač, Mihail S., Rossijskâ̂ èmigraciâ i krymskie karaimy vo Francii, [w:] Krymskie karaimy. Proishoždenie, ètnokul'tura, istoriâ, Simferopol': Dolâ, 2005, s. 40-45.

Spis wykładów i grono nauczajace $w$ roku akademickim 1935/36, Wilno: Szkoła Nauk Politycznych w Wilnie, 1935.

Şapşaloğlu, Süreyya (= Szapszal, Seraja), Kırm Karai Türkleri, „Türk Yılı”, İstanbul: Yeni Matbaa 1928, s. 576-615 (współczesna edycja: Şapşaloğlu, Sereya, Kırm Karaî Türkleri, [w:] Yusuf Akçuraoğlu, Türk Ylı 1928, Arslan Tekin, Ahmet Zeki Izgöer (red.), Ankara: Türk Tarih Kurumu 2009, s. 605-650).

Tayyib Okiç, Muhammed, Çeşitli Dillerde Mevlidler ve Süleyman Çelebi Mevlidinin Tercemeleri, Atatürk Üniversitesi İslâmî İlimler Fakültesi Dergisi, nr I, Erzurum 1975, s. 17-78. Topali, Ljerka, Bibliografija za 1937. godinu (s dopunama za 1936.), „Etnografska istraživanja i građa” 1940, knj. 2, s. 173-214. 
Tyszkiewicz, Jan, Międzywojenne badania nad dziejami Tatarów litewsko-polskich w XVII stuleciu, „Przegląd Historyczny” 1985, 76, nr 2, s. 305-320.

Volkov, Sergej V. (ed.), „Učastniki Belogo dviženiâ v Rossii”: http://swolkov.org/2_baza_ beloe_dvizhenie/2_baza_beloe_dvizhenie_abc-01.htm [data dostępu: 11.09.2016].

Wróblewska, Urszula, Sytuacja oświatowa społeczności tatarskiej w Drugiej Rzeczypospolitej, „Klio” 2012, nr 21 (2), s. 159-188.

Zajcev, Iliâ V., Trudy i dni Alekseâ Akimoviča Olesnickogo. (Addenda k slovarû otečestvennyh turkologov), „Shidnij svit” 2009, nr 1, s. 5-12.

\section{Aneks}

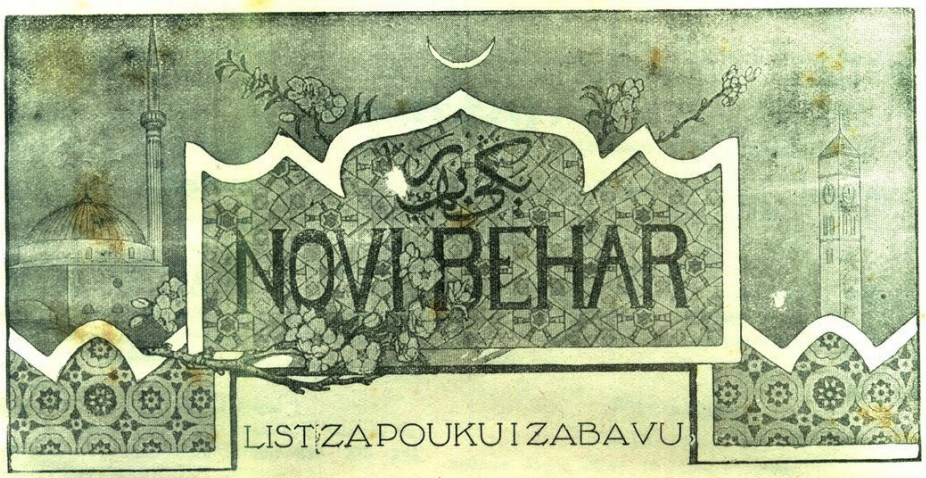

Ryc. I. Ozdobna winieta całości rocznika „Novi Behar”, tom X, 1936-1937. 


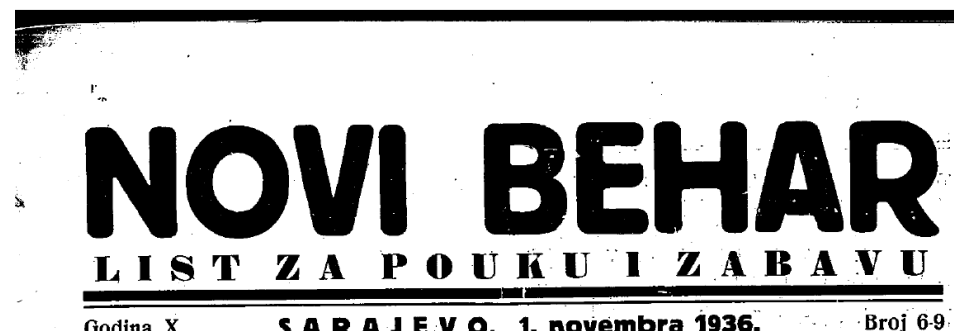

Godina $\mathrm{X}$.

S A R A J E V O, 1. novembra 1936.

Broj 6.9

\section{Našim pretplatnicima}

Dok drugi časopisi rijetko kada pišu o nemarnosti svojih pretplatnika, jzlazili oni kratko ili dugo rrijeme, dotle se mi čak na uvodnom mjestu obraçamo našim poštovanim pretplatnicima češće, računajući da ce nakon desete godine izlaženja lista uvidjeti, da se pretplata treba redovito plróati, bar tromjesečno unaprijed. U tom slučaju bi i Novi Behar izlawio svakih petnaest dana na šesnaest strana, kako to na omotu stoji.

Nećemo duljiti. Danaănji pretplatnici našeg časopisa, koji su svi dobri i pošteni ljudi, duguju do konca 0 . g. tj. do polovice X. godišta ništa manje nego Din. 98.667.25. Ne naznačujući im imena navodimo ih po mjestima i po broju, pa co se-tada svaki uviđavan čovjek uvjeriti, da nije na upravi Novog Behara krivnja, sto list izlazi u dvo-, tro- pa i četvorobrojima. Evo Vam toge iskaza:

Banja Luka (37*) Din. 4.832.50, Beograd (8) 1.315,- Bagrdan (1) 200.-, Berane (1) 125.-, Bijeljina (5) 840.-, Bihac (15) 2.177.50, Bos. Brod (7) 1425.-, Bos. Dubica (3) 350.-, Bos. Gradis̆ka (7) 1243.75, Bos. Kostajnica (3) 325.-, Bos. Krupa (8) 1152.50, Bos. Novi (4) 380.50, Bos. Otoka (3) 500._, Bos. Petrovao (7) 1112.50, Bos. Śamac (3) 475.,-, Branjevo (2) 580.-, Bratunao (2) 550.-, Brěko (18) 1930.-, Breza (2) 170.-, Brod n/S. (1) 150.-, Bugojno (2) 300.-, Bravsko (1) 50.-, Cazin (15) 2585.Cavtat (1) 50.-, Cakovec (1) 25.-, Cetinje (2) 125.—, Crkvice (1) 125.-, Cajụiče (2) 400.-, Capljina (11) 1180.-, Celio (5) 825.-, Cuprija

*) (37) brọ prețplatnika, koji duguju.
(1) 150.-, Derventa (16) 1887.50, Doboj (8) 1087.50, Donji Vakuf (7) 1005.-, Dubrovnik (3) 510.-, Domanović (1) 175.-, Đenović (2) 400.--, Fojnica (1) 125.-, Foča (10) 1335:-, Gabela (3) 250, -, Gacko (1) 100.—, Gračanica (16) 2405.-, Glamoě (7) 767.50, Gornji Vakuf (4) 600.-, Gostivar (1) 250.-, Gradačao (4) 575. - Goražde (7) 785.-, Hadžići (2) 275.Hankomp. Vitez (1) 37.50, Han Pijesak (1) 25.-, Herceg Novi (1) 75 ,-, Ilidža (1) 50.-, Jajce (8) 975.-, Janja (2) 325.—, Kakanj (5) 1050.-, Karlovac (2) 400.-, Kifino selo (1) 250.-, Kiseljak (1) 200, -, Kladanj (2) 125., Knin (1) 25.-, Klenike (1) 100_-, Ključ (7) 1080.-, Koraj (1) 50.-, Konjic (9) 590.-, Kotor Varoš (8) 927.50, Kulen Vakuf (5) 800.-, Kozarac (3) 250.-, Livno (4) 500.-, Loznica (1) 225.-, Ljubljana (1) 200.-, Ljubija (1) 150.-, Ljubinje (2) 175.-, Lukavao (2) 135.-, Ljubuški (9) 1116.50, Maglaj [4] 250.-, Mrkonjic Grad [4] 625.-, Mostar [33] 2632,-, Nevesinje [3]

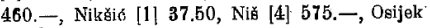
[1] 125.-, Oras̆je n/S. [2] 87.50 , Ostrožac [1] 200.-, Peć [2] 125.-, Podgorica [5] 525.-, Plevlje [8] 1475.-; Prača [1] 50., Prijeljina [1] 50-, Prijedor [7] 662.50, Prijepolje [4] 225.-, Prnjavor [4] 650.-, Prozor [9] 800.-, Puračić [:] 4ว̆0.-, Rogatica [10] 712.50, Rudo [1] 250.-, Sanski Most [4] 322.50, Sarajovo [182] 15547.50, Semizovac [2] 650.-, Split [2] 100.-, Skoplje [12] 2050.-, Srebrenioa [1] 12.50 , Sremska Mitrovica [1] 150-, Stari Majdan. (3) 250.-, Stolac (7) 950.- Srbac (1) 195:- Sutomore (1) 150.-, Tivat (1) 50.-,

Ryc. 2. Strona tytułowa, nr 6-9. 
ili ako je muž nesposoban za vrženje svojih bračnih dužnosti itd. itd; da pored svega toga budu prisiljeni na zajednički život ili što je još gore da žive odrojenim zivotom, pa cak i u konkubinatu s drugima, a da so ipak ne mogu rastaviti? Zar nije bolja i rastava braka nego viečite i nesnošljive muke oba bră̌na druga? Koliko samoubijstava, koliko moralnih i materijalaih propadanja je posljedica takve nesnosne i nerastavlijive bračne zajednice? Koliko ih $\mathbf{I}$ svoju yieru napusti, samo da bi se riješili tog nusnosnog života?

Samo govoredi o toj seriatskoj dozvoli moramo imati na umu da ni šeriat ne reče: „Ako vam dosadi jedna žena i zasitite jo se ili vidite drugu koja vam se od nje više svida, a vi je odmah otjerajte i uzmite tu drugu", kakso se to, nažalost, kod nas vrlo cesto çini i na taj način : se zlorabi taj uzvišeni islamstri propis, - nego nam se dozvoli samo kao manje zlo i to pošto smo iserpili sva druga sredstva za rješenje spora i uklanjanje nezgoda, kako to vidimo iz ovih kur'anskih rijeçi:

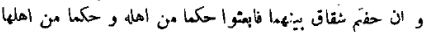

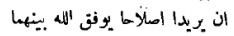

(Budete li se bojali razdora među njima, a vi izaberite i posaljite osobu od njegove i osobu od njezine rodbine [da jzglade spor], pa ako budu htjeli izmirenje, Bog co ih u tom pomooi).

Da se rastava braka doźvoljava samo bao skrajna nužda svjedoče nam i riječi Božjeg poslanika:

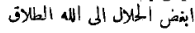

(Bogu najmrža dozvola je rastava braka).

Iz navedenoga jasno vidimo da rastava braka onakva i u onakvom ohliku kako je Islam propisuje nije i ne može biti štetna i neopravdana, nego naprotiv da je od nedokučive koristí i potpuno prirodna i opravdana. (Nastaviće se)

\section{H. Meh med handżét:}

\section{Karaimi (Karaiti).}

Koncem mjeseca jula i početkom augusta ove a jma ih jedna hiljada i u Poljakoj, gdje su sačuvali godine boravila je u Sarajevu jedna grupa Poljaka i svoj narodni jezik.

mẹdu kojima je bila i jedna muslimanka po imenu Safije hanuma. Voda te ekskurzije bio je g. Surejja bey Š̀ašal, profesor na visokoj politickoj školi u Vilnu u Poljskoj. Surejia bey poznajo turski, perzijski, tatarski, uzbekski, ruski, francuski, poljski i jos̆ neke druge jezike. Perzijski je naư⿱io boraved́ u Perziji osam godina kao uð̃itelj perzijskłog prestolonasljednika Prije rata bio je profesor a univerzitetu u Petrogradu. Tu jo druao predavanja iz orijentalistike. Poljski muftija Dr. Jakub Sijenkijeví́ je njegov đak. Osim toga Surejja bey je znamenita ličnost i po tome sto je on duhovai poglavica sekte Karaima (Karaits) na cijelom svijetu, Ovim povodom progovorićemo nekoliko rijeði o toi sekti.

Karaimi su jedna židovska sekta, koja se daleko udaljila od židovskog učenja, to je Ľidovi smatraju heretickom sektom. Dakle postoji bitna razlika u samoj vjeri između Z̆idova i Karaima. Osim toga postoji jos̆ jedus razlika izmedu ajih, koja ih je mnogo rastavila i jedne od drugih udaljila. Ta razlika je $u$ tome, sto je vecina Karaima turskog porijekla, a nijesu Hebreji. Ta sekta tvrdi da slijedi Musa-alejhiselamia, ali ne pripada Izraelskom narodu. Karaima ima $i$ takvih koji gu Izraelske krvi. Tu su oni što žive oko Jerugalima i u Misiru. Ima ih i slavenske krvi, a to su oni oko Astrahana i u nekim drugim mjestima bivše Rusije. Najveda većina ih je turske krvi i borave na Krimu,

Karaimi odbacuju Talmud $\mathrm{i}$ svu usmenu vjersku predaju i rabinsku literaturu. Oni priznaju samo Bibliju. Biblija krimskih Karaima je na cistom turskom jeziku, a na taj jezik jo još u jedanaestom stoljeću po Isa-alejhiselamu prevedena. Oni slave subotu, a molitva im je jutrom i voderom. Bogomolje su im okrenute prema Jerusalemu. Na Krimu ima dosta takvih bogomolja i izgledaju vrlo sliěne muslimanskim džamijama: izputra su prostrte halijama ili hasurama $i$ svak mora skinuti obuéu kada ulazi u bogomolju. Pred bogomoljom imadu česme za propisno cišcenje. Prema priđanju Surejia beya mnogi muslimani na Kri. mu, koji stanuju a blizini karaimskih bogomolja, cesto klanjaju po sobi namaz i u njihovim bogomoljama. Tamošnji ih muslimani zovu imenom "Mutiiislam“ t. j. islamu pokornima. On tyrdi da se na onim mjestima gdje nema muslimansbog groblja muslimani kopaju u njihovu grobliu i obratno, gdje nema karaimskog groblja da se Karaimi kopaju u muslimansko groblje. U koliko jo ovo ta.̌no ja mislim da su to ipak vrlo rijetlki sludajevi.

Kod Karaima je vrlo zanimljivo to sto vjeruju i Isa alojhiselama i Muhamed-alejhiselama, iako ne onako kako islam traži. Za Isa-alejhiselana kažu da je dobar covjek i sasvim ga poštuju. On nije usnovao vieru, koja se protivi T'evratu, nego je svojom dužnošću smatrao pomagati i provoditi odredbe njegove. Za

Ryc. 3. Początkowa strona artykułu M. Handžića Karaimi (Karaiti) 